Research Article

\title{
Clavicle fracture open reduction internal fixation: results of modern technique
}

\begin{abstract}
Background: Clavicle fractures are common. Surgical treatment of displaced clavicle fractures is controversial. We present our experience with 68 patients over an 11 year period.

Methods: Sixty-eight patients underwent open reduction and internal fixation (ORIF) of displaced, closed clavicle fractures and non-unions. Most fractures demonstrated comminution. Modern plate fixation was used in all cases. The majority of patients underwent local bone graft application at the fracture site.
\end{abstract}

Results: All patients went on to complete union at an average of 135 days after surgery. No major complications were identified. Five patients required a second surgery for symptomatic hardware removal.

Conclusion: ORIF of displaced clavicle fractures and nonunions is a reliable treatment with predictable outcomes when fundamentals of fracture fixation and soft tissue technique are followed.

Keywords: Clavicle, Fracture, Surgery, Non-union, ORIF
Volume 8 Issue I - 2017

\begin{abstract}
Taylor L Simonian,' Lauren E Simonian,' Peter T Simonian ${ }^{\prime, 2}$

'Simonian Sports Medicine Clinic, USA

${ }^{2}$ Clinical Associate Professor, Department of Orthopaedic

Surgery and Sports Medicine, University of Washington, USA
\end{abstract}

Correspondence: Peter T Simonian, MD, Simonian Sports Medicine Clinic, 729 N Medical Center Drive West, Suite 10I, Clovis, CA 936II, USA, Email ptsimonian@earthlink.net

Received: April 09, 2017 | Published: April 20, 2017

\section{Introduction}

Clavicle fractures are common. Clavicle fractures account for 2.6 $\%$ of all fractures and $44 \%$ of those in the shoulder girdle. Fractures of the middle third of the clavicle are most common (81\%). ${ }^{1}$

Surgical treatment of displaced clavicle fractures is controversial. Traditionally, these fractures have been treated non-operative..$^{2-6}$ This traditional treatment is not without complications, including shortening, nonunion, deformity and unsatisfactory patient outcomes. ${ }^{7-14}$ More recently, modern operative treatment has demonstrated superior results. ${ }^{15-26}$

We present our experience with 68 patients over an 11 year period. All treated with modern open reduction and internal fixation (ORIF) technique leading to union in all cases without serious complication.

\section{Materials and methods}

During a 11 year period (2003-2014), sixty-eight patients with an average age of 34 years (14-77) underwent ORIF of an acute clavicle fracture an average 30 days after injury (62) or non-union (6) 165 days after injury. In all cases, the incision was placed along the superior border of the clavicle. All acute fractures were reduced anatomically with minimal soft tissue stripping or devitalization.

All factures were closed. All fractures were displaced. Fifty-Nine fractures demonstrated comminution and nine did not.

Sixty-one fractures were mid-shaft (Figure 1) and seven were distal third (Figure 2) or had a distal component.

Forty-five patients had local autologous bone graft added at the fracture site. This was usually taken from the comminuted fragments that did not lend themselves to direct reduction. No bone graft was harvested from a separate site.

Fixation included precontoured clavicle plates (Synthes (Paoli, PA), Acumed (Hillsboro, OR), and Smith \& Nephew (Memphis, $\mathrm{TN}$ ) in 62 patients (Figures $1 \& 2$ ), a reconstruction plate (contoured at the time of surgery) in 5 patients, and a LCDC plate was used in one patient. Regardless of the plate, locking screw fixation was used distally when bone quality was compromised. Sixty-six of the plates were placed superiorly and or anterior with 2 plates placed in the inferior position.

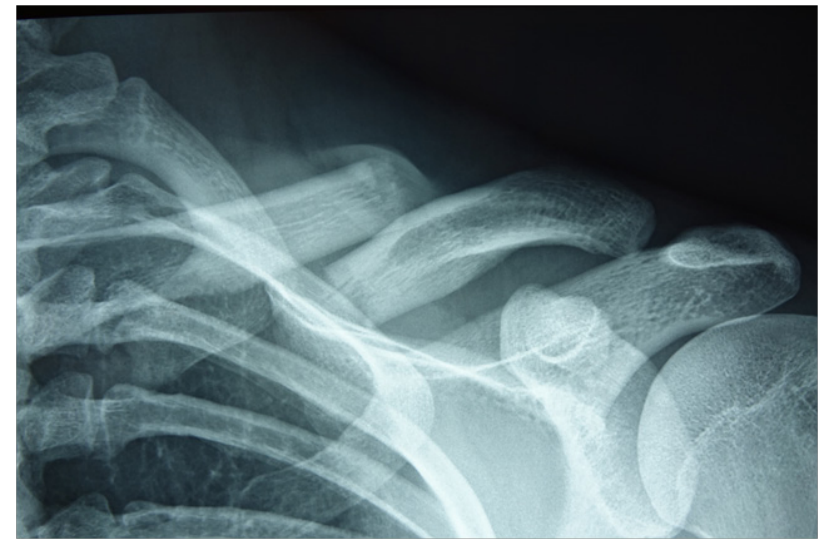

Figure IA Displaced midshaft clavicle fracture.

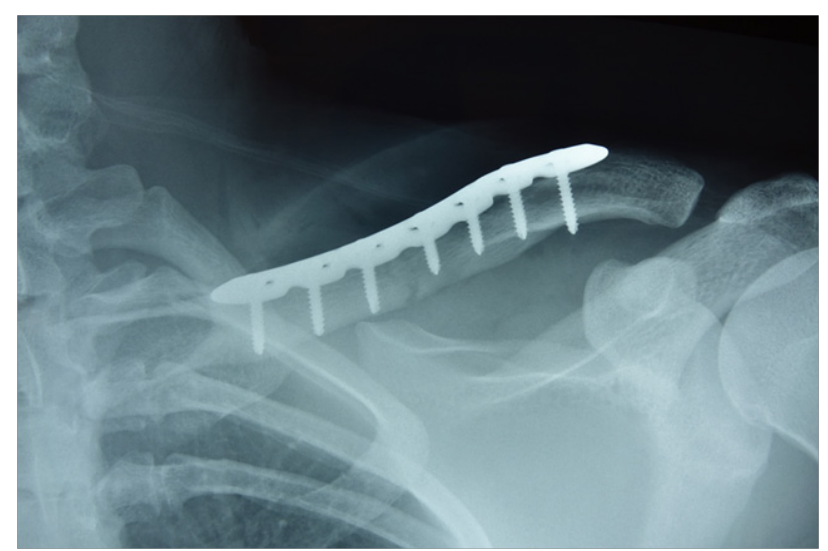

Figure I B Typical fixation used for midshaft clavicle fracture patterns with pre-contoured plate. 


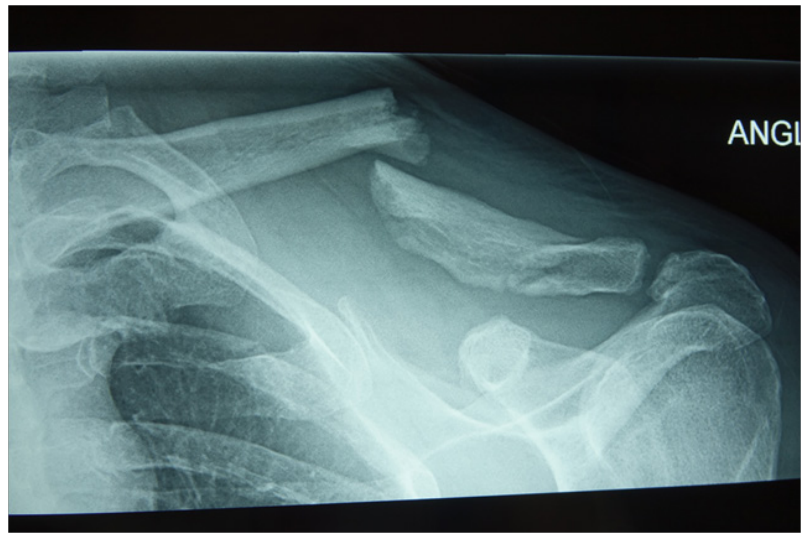

Figure 2A Displaced segmental clavicle fracture with distal fragment.

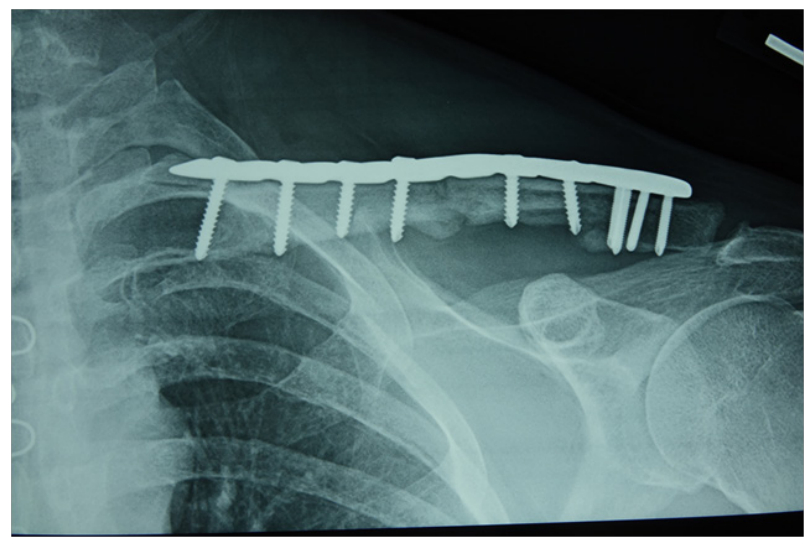

Figure 2B Typical fixation used for distal fracture patterns with precontoured plate.

Nearly all fixation constructs included at least 8 cortices of fixation on the distal fragment and 6 cortices of fixation on the medial fragment (Figure 1b). Additional interfragmentary screws were used when appropriate. The only time that the number or cortices were less than 8 distal and 6 medial is when multiple interfragmentary screws were utilized.

Meticulous technique was used to prevent neurovascular injury during dissection, reduction, and fixation. All fractures were treated by a single surgeon.

\section{Results}

All fractures (100\%) went on to complete union with no hardware failures. All patients had achieved complete boney union at an average of 135 days after surgery.

There were no infections, neurovascular injuries, or other major complications. All patients had symmetric range of motion when compared to the contralateral side at the time of fracture union. The majority of patients had some degree of parasthesia on the inferior side of the incision.

Five patients underwent a second surgery for hardware removal, secondary to symptomatic hardware prominence.

\section{Discussion}

Beginning with classic papers by $\mathrm{Neer}^{22}$ and Rowe, ${ }^{24}$ most authors recommended that ORIF of displaced midshaft clavicle fracture should be avoided because of the high rate of union with non- operative treatment, high rate of failure with operative treatment, and the potential risk of neurovascular complications due to the close proximity of vital structures including the underlying subclavian artery, vein, brachial plexus, and pleura.

Over 25 years ago, Jupiter \& Leffert ${ }^{19}$ noted that fracture displacement of greater than $2 \mathrm{~cm}$ was associated with non- union in their series of patients. Since then, the treatment of displaced midshaft clavicle fractures has evolved. Recent clinical studies demonstrate high rates of nonunion and symptomatic malunion with non-operative treatment. ${ }^{15}$

In our series of 68 patients with midshaft and distal third fractures and non-unions of the clavicle, we found $100 \%$ union rate with no major complications. Skin parasthesia was the only minor complication, and all patient's had been counseled preoperatively of this high potential. We attribute our outcome to meticulous surgical technique including minimal devitalization of soft tissues providing blood supply to the bone, anatomic reductions whenever possible, and following established principles for internal fixation. Local bone graft was used when appropriate in more than half the cases. Evolved plating systems designed specifically for the clavicle have also made a difference in fixation success and minimizing the need for hardware removal.

\section{Conclusion}

In a review of 68 patients in an 11 year period, ORIF of displaced clavicle fractures and nonunions proved to be a reliable treatment with predictable outcomes when fundamentals of fracture fixation and soft tissue technique are followed. All patients went on to fracture union without major complication. Five patients required hardware removal.

\section{Acknowledgments}

None.

\section{Conflicts of interest}

None.

\section{References}

1. Postacchini F, Gumina S, De Santis P, et al. Epidemiology of clavicle fractures. J Shoulder Elbow Surg. 2002;11:452-426.

2. Kashif Khan LA, Bradnock TJ, Scott C, et al. Fractures of the clavicle. Current concepts review. J Bone Joint Surg Am. 2009;91:447-460.

3. Kulshrestha V. Primary Plating of Displaced Mid-shaft Clavicular Fractures. Med J Armed Forces India. 2008;64(3):208-211.

4. Langenberg R. Therapy of clavicular fractures and injuries of adjacent joints: when is a surgical, when is a conservative procedure indicated? Beitr Orthop Traumatol. 1987;34(3):124-131.

5. McKee MD, Wild LM, Schemitsch EH. Midshaft malunions of the clavicle. Surgical Technique. J Bone Joint Surg Am. 200486(Suppl 1):37-43.

6. Stanley D, Trowbridge EA, Norris SH. The mechanism of clavicular fracture. A clinical and biomechanical analysis. J Bone Joint Surg Br. 1988;70(3):461-4.

7. Chen C, Chen J, Wang C, et al. Semi tubular Plates for Acutely Displaced Midclavicular Fractures: A Retrospective Study of 111 Patients Followed for 2.5 to 6 Years. J Orthop Trauma. 2008;22(7):463-466.

8. Echtermeyer V, Zwipp H, Oestern HJ. Errors and dangers in the treatment of fractures and pseudarthroses of the clavicle. Langenbecks Arch Chir. 1984;364:351-354. 
9. McKee MD, Wild LM, Schemitsch EH. Midshaft malunions of the clavicle. J Bone Joint Surg Am. 2003;85-A(5):790-797.

10. Paffen PJ, Jansen EW. Surgical treatment of clavicular fractures with Kirschner wires: a comparative study. Arch Chir Neerl. 1978;30(1):43-53.

11. Robinson CM, Cairns DA. Primary nonoperative treatment of displaced lateral fractures of the clavicle. J Bone Joint Surg Am. 2004;86-A(4):778-782

12. Robinson CM, Court Brown CM, McQueen MM, et al. Estimating the risk of nonunion following non operative treatment of a clavicular fracture. J Bone Joint Surg Am. 2004;86-A(7):1359-1365.

13. Schmit-Neuerburg KP, Weiss H. Conservative therapy and treatment results in clavicular fractures. Hefte Unfallheilkd. 1982;160:55-75.

14. Smekal V, Irenberger A, Struve P, et al. Elastic stable intra medullary nailing versus non operative treatment of displaced midshaft clavicular fractures-a randomized, controlled, clinical trial. J Orthop Trauma. 2009;23(2):106-112.

15. Canadian Orthopedic Trauma Society. Nonoperative treatment compared with plate fixation of displaced midshaft clavicle fractures. A multi center, randomized clinical trial. J Bone Joint Surg Am. 2007;89(1):1-10.

16. Effenberger T. Clavicle fractures: treatment, follow-up studies. Chirurg. $1981 ; 52(2): 121-4$.

17. Eskola A, Vainionpaa S, Myllynen P, et al. Outcome of clavicular fracture in 89 patients. Arch Orthop Trauma Surg. 1986;105(6):337-338.
18. Hill JM, McGuire MH, Crosby LA. Closed treatment of displaced middle-third fractures of the clavicle gives poor results. $J$ Bone Joint Surg Br. 1997;79(4):537-539.

19. Jupiter JB, Leffert RD. Non-union of the clavicle. Associated complications and surgical management. J Bone Joint Surg Am. 1987;69(5):753-760.

20. McKee MD, Pedersen EM, Jones C, et al. Deficits following non operative treatment of displaced midshaft clavicle fractures . J Bone Joint Surg Am. 2006;88(1):35-40.

21. Nordqvist A, Petersson CJ, Redlund-Johnell I. Mid-clavicle fractures in adults: end result study after conservative treatment. J Orthop Trauma. $1998 ; 12: 572-576$

22. NeerCS. Nonunion of the clavicle.JAm MedAssoc. 1960;172:1006-1011.

23. Nowak J, Holgersson M, Larsson S. Sequelae from clavicular fractures are common: a prospective study of 222 patients. Acta Orthop. 2005;76(4):496-502.

24. Rowe CR. An atlas of anatomy and treatment of mid clavicular fractures. Clin Orthop Relat Res. 1968;58:29-42.

25. Virtanen KJ, Remes V, Pajarinen J, et al. Sling compared with plate osteosynthesis for treatment of displaced midshaft clavicular fractures. A randomized clinical trial. J Bone Joint Surg Am. 2012;94(17):1546-1553.

26. $\mathrm{Xu} \mathrm{J}, \mathrm{Xu} \mathrm{L}, \mathrm{Xu} \mathrm{W}$, et al. Operative versus non operative treatment in the management of midshaft clavicular fractures: a meta-analysis of randomized controlled trials. Journal of Shoulder and Elbow Surgery. 2014;23(2):173-181. 